\title{
EXAMINATION OF THERMAL BALANCE OF VERTICAL GREEN MOBILE WALL
}

\author{
Vladimir Masan ${ }^{1}$, Patrik Burg ${ }^{1}$, Pavla Bukovska ${ }^{1}$, Jakub Sikora ${ }^{2}$ \\ ${ }^{1}$ Mendel University in Brno, Czech Republic; ${ }^{2}$ University of Agriculture in Krakow, Poland \\ vladimir.masan@mendelu.cz
}

\begin{abstract}
The trend of urbanism in the cities is to reduce the amount of green areas. These green areas cannot compete with the financial force of developers, and therefore they are built in a vertical shape instead of the horizontal one and as a living wall system (LWS). In this form, they are able to reduce the urban heat island (UHI) and have positive effects on building improved thermal environment as well as other benefits. Unfortunately, there are still areas, such as historic centres of towns, squares and parking slots, where no areas are suitable for the living wall system. On the other hand, specifically these areas are suitable for the mobile version of green walls. This study examines the influence on lowering the temperature of the mobile version of LWS developed at the Mendel University in Brno. The evaluation is based on comparing the surface temperature of buildings, the surface temperature of LWS while dry and the surface temperature of LWS after irrigating. The effect was observed in the thermographic pictures of the mobile version of LWS by comparison to the reference wall. The study aims at evaluating the real possibilities of the LWS system on lowering the temperature of surfaces in the urban area as well as the possibilities of the system on lowering the problem with UHI. The results confirmed the expected lower temperature of the surface approximately about 13,2\% at LWS while dry and $28 \%$ after irrigation in comparison to the regular surface without LWS cover. Similarly, the effect of balanced extreme temperatures during the day was examined, as the irrigation water was able to remove the high temperature of the LWS surface and significantly contributed to the cooling effect. Moreover, there was no radical stress level of plants recorded on the vertical green mobile system. Otherwise, that would negatively affect the positive functions of such solution.
\end{abstract}

Keywords: temperature, irrigation, urban, green wall.

\section{Introduction}

The trend of urbanism in the cities is to reduce the amount of green areas that cannot compete with the financial force of developers. One of the possibilities of green situation is utilisation of the building's roofs, but large proportion of rooftop is occupied by devices, such as water tanks, elevator machinery and solar panels, resulting in a very little space for greening. Vertical planting is certainly an alternative to roof greenery in a city $[1 ; 2]$.

The green areas are important for air cleaning, rainwater collecting, gas emission and noise reducing, protecting urban biodiversity and UHI reducing [3-6]. The primary cause of the UHI effect is the absorption of solar radiation by the mass of building structures, roads, and other hard surfaces during daytime and the emission of the heat stored in the mass into the atmosphere later at night $[7 ; 8]$. Applying some types of the vertical greenery system (VGS) on buildings can be utilised as one of the technologies of UHI reducing [9-11].

Green Facade (GF) system is the most elementary, with the climber plants growing on the building facade. This system is undemanding on investments, but with little effect on UHI reductions. Therefore, the living wall system (LWS) has been developed. It is a complex technology that includes the waterproof layer, the plant and soil containers, the irrigation and drainage system and the water control machine [12]. The use and positive effect of LWS on UHI reduction are well analysed [1214].

This paper states the results of the study examining the influence of a mobile version of LWS on lowering the temperature. The mobile version was developed at the Mendel University in Brno and it is available for public spaces, such as historic city centres or parking areas, where a small amount of greenery is caused by a care of historical monuments, by the use of place for parking slots and by a presence of façades unfit for greening.

\section{Materials and methods}

The experiment was conducted from 1 May 2018 to 30 September 2018 at the Mendel University in Lednice, Czech Republic (48.80N, 16.80E), altitude $173 \mathrm{~m}$ a.s.l. This area is in a temperate climate zone, characterized by long summers with a very warm and dry season. The external air temperature was measured by the local weather station. Only the data, when the daytime temperature (measured at 
$2 \mathrm{pm}$ ) exceeded $30^{\circ} \mathrm{C}$ (Tropical day - maximum air temperature must be above $30^{\circ} \mathrm{C}$ ), were included in the experiment and when it was not raining at the hour of measurement. In order to reduce the possible interference by raining, the data were used only when the weather stayed hot and dry. The measured values are summarized in Table 1.

In the first stage of the research project, two types of walls were observed. Beside the mobile version of LWS, one brick facade wall with polystyrene heat isolation was chosen for comparison. In both cases, the wall surface was without shading and it was west-southwest orientation to allow it to receive maximum afternoon sunlight in summer.

The mobile version of LWS characterized by a width of $2.00 \mathrm{~m}$, a height of $2.00 \mathrm{~m}$ was composed of a metal structure, with a PVC panel installed on it, and three felt layers. From the felt layer a framework is created that allows the roots of the plants to propagate. Plants are in eight rows with 8 plants per row. The plants were irrigated with the drip method that allows to provide through each nozzle $2.0 \mathrm{l} \cdot \mathrm{h}^{-1}$ of water. Each plant has one nozzle. The surplus of water drained off by the plants is collected on a $1.2 \mathrm{~m} 3$ catchment tank at the bottom of the structure. Some perennial plants were used for the experiment, for example, Sedum spurium, Ajuga reptans, Heuchera sp., Festuca sp., Hosta sp., Achillea sp. and others.

The temperature of the external plaster surface and is created surface of the mobile version of LWS exposed to the solar radiation was measured using the visual IR thermometer Fluke V T04 (Fluke Corporation, USA). Data were measured three times in one point in the centre of the area and then averaged. The values of LWS were measured before and after irrigation.

The data were reported as means \pm standard deviation. Analysis of variance was conducted and the results were compared using the Tukey's multiple range test $(\alpha=0.05)$. A statistical analysis was carried out using the software package "Statistica 12.0" (StatSoft Inc., Tulsa, Oklahoma, USA).

\section{Results and discussion}

The external surface temperature of the building wall was chosen for assessing the cooling performance of the mobile LWS. According to the presumptions, the presence of the vegetation layer mitigated the temperature of the tested area. During the daytime, the temperature of the control wall was always higher than the external wall temperature of LWS. The effect of vegetative cooling was kept within a range of $4.8-7.5^{\circ} \mathrm{C}$ between the control wall and the LWS before irrigation. The maximum reduction of temperature was recorded on 29 July 2018 at 2 p.m. The effect between the control wall and LWS after irrigation was within a range of $9.9-16.1^{\circ} \mathrm{C}$. The maximum temperature difference was recorded on 9 August 2018 at 2 p.m. (Table 1).

The daily temperatures recorded on the control wall were statistically higher than the values recorded on the LWS. The mitigation of the wall surface temperature due to the plants was observed throughout the season (higher temperature equals higher difference). As shown in Table 1 and Figure 1 , the average values of temperatures recorded on the control wall were mainly higher than the values recorded on the mobile LWS. This green technology showed its cooling effect during the daytime that is in accordance with the conclusions presented by VOX et al. [15]. Pérez et al. [8] reported the reduction of the external building surface temperature in the range from $1.7^{\circ} \mathrm{C}$ to $13^{\circ} \mathrm{C}$ in warm temperate climate regions. Eumorfopoulou and Kontoleon [16] also reported a temperature reduction in the range varying from $1.9^{\circ} \mathrm{C}$ to $8.3{ }^{\circ} \mathrm{C}$, in average to $5.7^{\circ} \mathrm{C}$. Susorova et al. [17] published similar results with use of climbing vegetation: an average decrease of the facade surface temperatures from $1.0^{\circ} \mathrm{C}$ to $9.0^{\circ} \mathrm{C}$ during summer. Cameron et al. [18] also confirm good cooling effect of green walls.

Thermal image (Fig. 1) showing that the temperature of the reference facade (a) is higher than the LWS temperature before irrigation (c) and LWS temperature after irrigation (d). Image (b) showing the plant coverage of the wall area. In Figure 1 (d), the effect of incomplete coverage by the plants at the edges of the wall area can be seen, resulting in higher temperatures.

Figure 1 (b) and 1 (c) also show that some parts of the wall are less green and show a higher temperature. It is due to the planting in the same year as the experiment was conducted. The plants grew on the wall only in the first season, so they did not reach the full wall coverage. However, the cooling effect was significant. 
Measured values of temperature of air, facade and LWS before and after irrigation $(n=3)$

\begin{tabular}{|c|c|c|c|c|}
\hline \multirow[b]{2}{*}{ Date } & \multirow[b]{2}{*}{$\begin{array}{c}\text { Air } \\
\text { temperature, }{ }^{\circ} \mathrm{C}\end{array}$} & \multicolumn{3}{|c|}{ Experimental variant } \\
\hline & & $\begin{array}{c}\text { Facade } \\
\text { temperature, }{ }^{\circ} \mathrm{C}\end{array}$ & $\begin{array}{c}\text { LWS } \\
\text { temperature } \\
\text { before } \\
\text { irrigation, }{ }^{\circ} \mathrm{C} \\
\end{array}$ & $\begin{array}{c}\text { LWS } \\
\text { temperature } \\
\text { after } \\
\text { irrigation, }{ }^{\circ} \mathrm{C} \\
\end{array}$ \\
\hline 10.6 & 30.3 & $40.3 \pm 0.99$ & $35.5 \pm 0.00$ & $30.4 \pm 0.28$ \\
\hline 11.6 & 30.8 & $41.9 \pm 0.14$ & $37.0 \pm 0.14$ & $31.0 \pm 0.00$ \\
\hline 21.6 & 33.7 & $45.2 \pm 0.14$ & $39.0 \pm 0.00$ & $30.0 \pm 0.57$ \\
\hline 4.7 & 31.8 & $43.8 \pm 0.14$ & $38.2 \pm 0.14$ & $31.6 \pm 0.00$ \\
\hline 5.7 & 30.3 & $41.8 \pm 0.28$ & $36.4 \pm 0.07$ & $31.8 \pm 0.21$ \\
\hline 15.7 & 30.5 & $42.4 \pm 0.14$ & $36.8 \pm 0.00$ & $32.0 \pm 0.07$ \\
\hline 21.7 & 31.6 & $43.6 \pm 0.07$ & $38.3 \pm 0.00$ & $32.5 \pm 0.07$ \\
\hline 24.7 & 31.4 & $43.7 \pm 0.14$ & $38.2 \pm 0.14$ & $32.6 \pm 0.00$ \\
\hline 26.7 & 30.1 & $43.1 \pm 0.07$ & $37.6 \pm 0.00$ & $31.0 \pm 0.42$ \\
\hline 27.7 & 31.1 & $43.3 \pm 0.14$ & $37.7 \pm 0.07$ & $32.0 \pm 0.28$ \\
\hline 28.7 & 32.0 & $45.5 \pm 0.00$ & $39.7 \pm 0.00$ & $32.9 \pm 0.00$ \\
\hline 29.7 & 32.5 & $46.5 \pm 0.07$ & $39.0 \pm 0.14$ & $33.1 \pm 0.28$ \\
\hline 30.7 & 33.0 & $47.0 \pm 0.07$ & $41.1 \pm 0.07$ & $33.9 \pm 0.00$ \\
\hline 31.7 & 33.4 & $47.6 \pm 0.00$ & $41.6 \pm 0.00$ & $34.0 \pm 0.28$ \\
\hline 1.8 & 33.8 & $48.1 \pm 0.14$ & $41.3 \pm 0.07$ & $34.2 \pm 0.35$ \\
\hline 2.8 & 34.3 & $48.4 \pm 0.07$ & $42.2 \pm 0.00$ & $34.5 \pm 0.14$ \\
\hline 3.8 & 33.7 & $47.9 \pm 0.07$ & $41.5 \pm 0.07$ & $33.0 \pm 0.00$ \\
\hline 4.8 & 35.0 & $49.6 \pm 0.14$ & $43.1 \pm 0.00$ & $34.0 \pm 0.00$ \\
\hline 5.8 & 32.3 & $46.8 \pm 0.00$ & $40.3 \pm 0.07$ & $33.5 \pm 0.14$ \\
\hline 6.8 & 31.8 & $46.2 \pm 0.14$ & $39.8 \pm 0.00$ & $33.1 \pm 0.00$ \\
\hline$* 7.8$ & 33.3 & $47.6 \pm 0.14$ & $41.3 \pm 0.00$ & $34.0 \pm 0.42$ \\
\hline 8.8 & 35.4 & $50.4 \pm 0.07$ & $43.8 \pm 0.00$ & $34.5 \pm 0.07$ \\
\hline 9.8 & 35.7 & $50.8 \pm 0.00$ & $43.9 \pm 0.07$ & $34.7 \pm 0.00$ \\
\hline 10.8 & 31.6 & $46.5 \pm 0.07$ & $39.8 \pm 0.00$ & $33.1 \pm 0.07$ \\
\hline 12.8 & 30.6 & $45.4 \pm 0.00$ & $38.8 \pm 0.07$ & $32.1 \pm 0.14$ \\
\hline 13.8 & 33.8 & $48.2 \pm 0.07$ & $41.7 \pm 0.00$ & $34.8 \pm 0.07$ \\
\hline 16.8 & 30.1 & $44.0 \pm 0.14$ & $37.4 \pm 0.00$ & $31.5 \pm 0.00$ \\
\hline 17.8 & 32.1 & $46.1 \pm 0.07$ & $39.9 \pm 0.07$ & $33.2 \pm 0.14$ \\
\hline 18.8 & 34.4 & $48.6 \pm 0.07$ & $42.3 \pm 0.00$ & $34.7 \pm 0.14$ \\
\hline 19.8 & 34.4 & $47.6 \pm 0.14$ & $41.6 \pm 0.00$ & $34.9 \pm 0.07$ \\
\hline 20.8 & 35.6 & $49.1 \pm 0.07$ & $43.1 \pm 0.07$ & $34.8 \pm 0.00$ \\
\hline 21.8 & 30.9 & $42.9 \pm 0.00$ & $37.1 \pm 0.07$ & $32.1 \pm 0.42$ \\
\hline 22.8 & 32.6 & $44.4 \pm 0.07$ & $39.0 \pm 0.00$ & $33.8 \pm 0.07$ \\
\hline 23.8 & 33.5 & $45.8 \pm 0.00$ & $40.6 \pm 0.00$ & $33.9 \pm 0.21$ \\
\hline Average temperature, ${ }^{\circ} \mathrm{C}$ & 32.57 & $45.85 \pm 2.60^{\mathrm{a}}$ & $39.83 \pm 2.23^{\mathrm{b}}$ & $33.02 \pm 1.36^{\mathrm{c}}$ \\
\hline \multicolumn{3}{|c|}{ Temperature reduction, $\%$} & 13.17 & 28.00 \\
\hline
\end{tabular}

Legend: Data are expressed as means \pm standard deviation. Different letters represent significant difference $(p<0.05)$. * Photos in Figure 1 were taken on this day. 


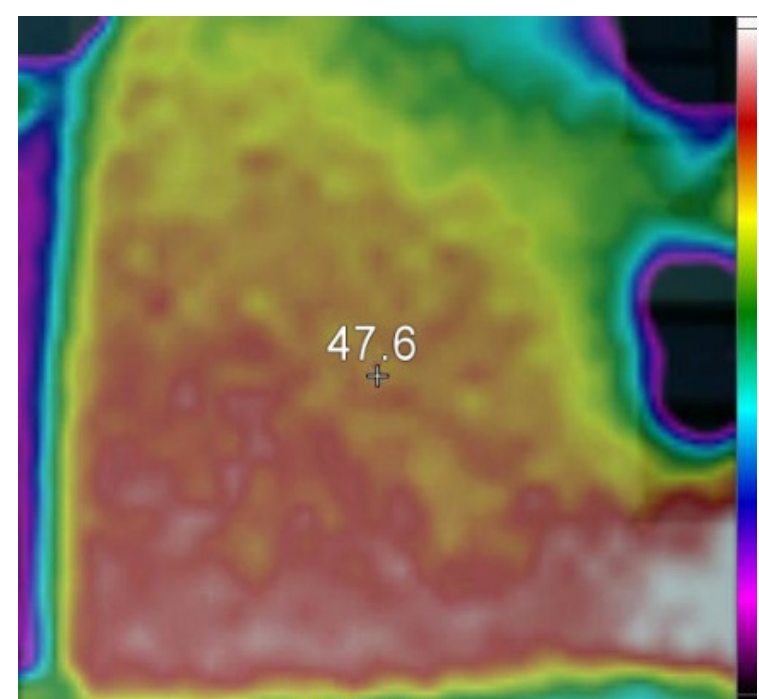

(a)

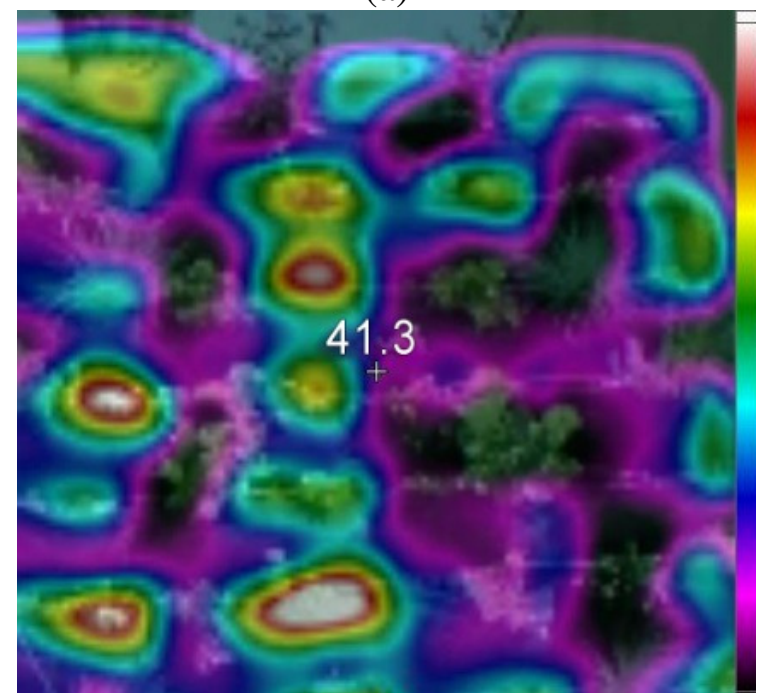

(c)

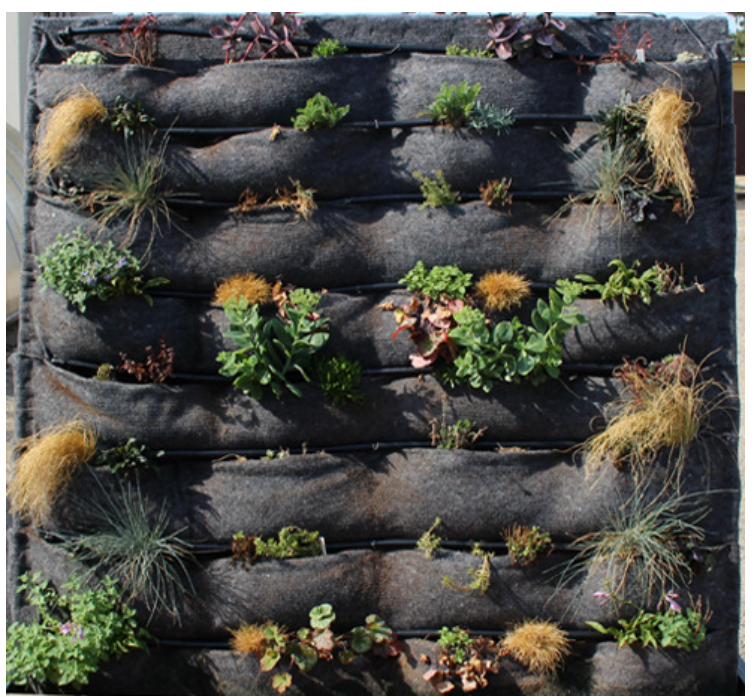

(b)

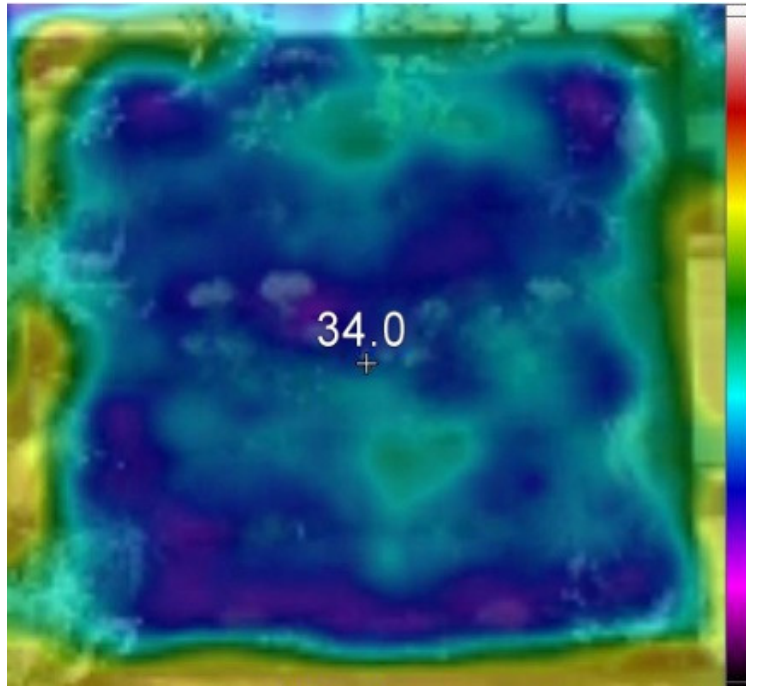

(d)

Fig. 1. Thermal image of wall: $a-$ facade; $b-L W S ; c-L W S$ before irrigation; $d-L W S$ after irrigation (The arrows show the measured temperature $\left({ }^{\circ} \mathrm{C}\right)$ on August 7, 2018 at $2 \mathrm{pm}$ in the centre of the walls)

The results are in a line with Cameron et al. [18], who in their work indicate a significant effect of vegetation, whereas some differences between the species of plants and types of technology are not that significant. Huang et al. [19] draw attention to the cooling and wetting effect of water itself, which is related to the technology, particularly whether a GF or LWS system is used. This view can be supported by the results presented in this paper, especially the significant reduction in the surface temperature after irrigation.

Other authors found that the additional cooling influence conferred by plants relates to their ability to better distribute cooling moisture from evapotranspiration water around a wall $[12 ; 15 ; 18$ 20].

When considering heat flows (cooling effect), the distribution of water in the substrate or in plants is usually not in consideration, especially with regard to the complexity of such a calculation [21]. However, the results of the experiment clearly demonstrate the need to account for the excess water that was not used by the plants and mostly flows down the wall into lower parts, and also with water bound in the substrate.

Figure 2 shows that the air temperature at the time of measurement is on the $\mathrm{x}$ axis. On the $\mathrm{y}$ axis the surface temperature is plotted for three cases: reference facade temperature, LWS temperature before irrigation and LWS temperature after irrigation (measured 15 minutes after irrigation). The 
points drawn for each case can be well approximated by a straight line. The statistical analysis confirmed that the cooling effect of LWS and irrigation increases with higher air temperature.

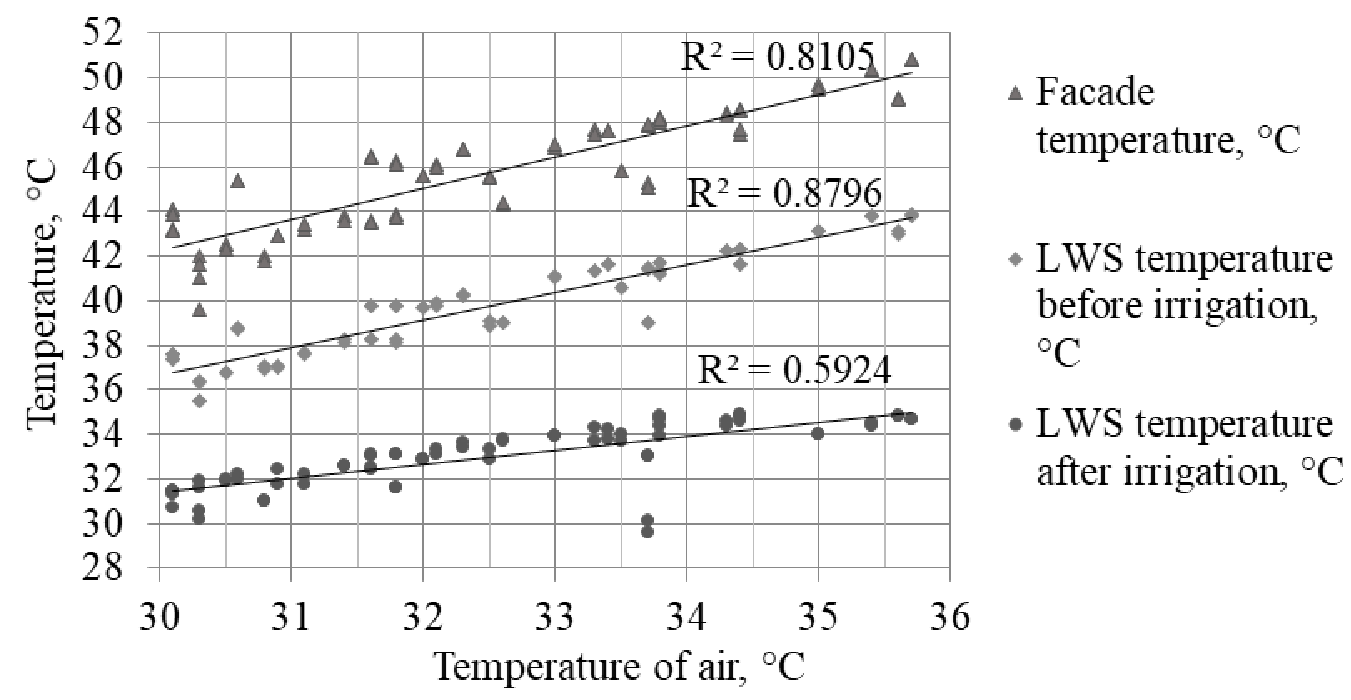

Fig. 2. Temperatures of air, reference facade, LWS before irrigation and LWS after irrigation

\section{Conclusions}

The cooling behaviour is desirable in warm periods. The experiment demonstrated the cooling effect of the LWS technology during summer time. The wall temperature with the LWS technology was significantly cooler than the control facade on both before and after irrigation. Thermal images of the wall and leaf surface temperatures confirmed the cooling effect of the vegetation. The largest difference between the temperatures at $2 \mathrm{p} . \mathrm{m}$. was $16.1^{\circ} \mathrm{C}$. The mean values of all measured temperatures were: $32.57{ }^{\circ} \mathrm{C}$ (air), $45.89^{\circ} \mathrm{C}$ (control wall), $39.84{ }^{\circ} \mathrm{C}$ (LWS before irrigation), $33.04{ }^{\circ} \mathrm{C}$ (LWS after irrigation).

The main conclusions that can be drawn from the presented results are the following.

1. The results related to the green facade based on the LWS technology show the surface temperature decrease by $16.1{ }^{\circ} \mathrm{C}$ compared to the temperature of the bare wall.

2. The cooling effect of water and all technology of LWS seems to be more significant in comparison with GF.

3. LWS technology is the most effective during the first year after installation. On the contrary, GF is a system when the plants are growing gradually, so it takes some years to become green in the whole area (especially on higher floors). The results shown in this research can fill the gap in understanding the influence of irrigating water on the cooling effect provided by LWS and the potential of increasing the air humidity in the vicinity of the wall. Knowledge of the thermal behaviour of the mobile version of LWS is important for architects and green managers, because it can help them to reduce UHI within urban areas design.

\section{Acknowledgements}

The research was financially supported by the project IGA-ZF/2018-DP001 - Design and verification of mobile green walls.

\section{References}

[1] Heng C.Y., Cheung K.K.S., Chu L.M. Thermal performance of a vegetated cladding system on facade walls. Building and Environment, vol. 45, 2010, pp. 1779-1787.

[2] Perini K., Rosasco P. Cost-benefit analysis for green facades and living wall systems. Build. Environ., vol. 70, 2013, pp. 110-121.

[3] Prodanovic V. Hatt B., McCarthy D. etc. Green walls for greywater reuse: Understanding the role of media on pollutant removal. Ecological Engineering, vol. 102, 2017, pp. 625-635. 
[4] Mitterboeck M., Korjenic A. Analysis for improving the passive cooling of building's surroundings through the creation of green spaces in the urban built-up area. Energy and Buildings, vol. 148, 2017, pp. 166-181.

[5] Hoelscher M.T., Nehls T., Jänicke B. etc. Quantifying cooling effects of facade greening: shading. transpiration and insulation. Energy and Buildings, vol. 114, 2015, pp. 283-290.

[6] Schettini E., Campiotti C.A., Scarascia Mugnozza G. etc. Green walls for building microclimate control. Acta Horticulturae, vol. 1215, 2018, pp. 73-76.

[7] Park J.E., Murase H. Evapotranspiration efficiency of sunagoke moss mat for the wall greening on the building. American society of agricultural and biological engineers annual international meeting, June 29 - July 2, 2008, Providence, Rhode Island, pp. 3612-3621.

[8] Pérez G., Coma J., Martorell I. etc. Vertical greenery systems (VGS) for energy saving in buildings: a review. Renew. Sustain. Energy Rev., vol. 39, 2014, pp. 139-165.

[9] Tsilini V., Papantoniou S., Denia Kolokotsa D. etc. Urban gardens as a solution to energy poverty and urban heat island Sustainable Cities and Society, vol. 14, 2015, pp. 323-333.

[10] Aflaki A. Mirnezhad M., Ghaffarianhoseini A. etc. Urban heat island mitigation strategies: A state-of-the-art review on Kuala Lumpur. Singapore and Hong Kong Cities, vol. 62, 2017, pp. 131-145.

[11] Manso M., Castro-Gomes J. Green wall systems: a review of their characteristics. Renewable and Sustainable Energy Reviews, vol. 41, 2015, pp. 863-871.

[12] Lin H., Xiao Y., Musso F. Shading effect and heat reflection performance of green facade in hot humid climate area: measurements of a residential project in guangzhou. IOP Conference Series: Earth and Environmental Science, May 2018, China, 146, 012006.

[13] Bianco L., Serra V., Larcher F. etc. Thermal behaviour assessment of a novel vertical greenery module system: first results of a long-term monitoring campaign in an outdoor test cell. Energy Efficiency, vol. 10, 2017, pp. 625-638.

[14] Pérez G., Coma J., Sol S. etc. Green facade for energy savings in buildings: The influence of leaf area index and facade orientation on the shadow effect. Applied Energy, vol. 187, 2017, pp. 424-437.

[15] Vox G., Blanco I., Schettini E. Green façades to control wall surface temperature in buildings. Building and Environment, vol. 129, 2018, pp. 154-166.

[16] Eumorfopoulou E.A., Kontoleon K.J. Experimental approach to the contribution of plant-covered walls to the thermal behaviour of building envelopes. Build. Environ., vol. 44, 2009, pp. 1024-1038.

[17] Susorova I., Azimi P., Stephens B. The effects of climbing vegetation on the local microclimate. thermal performance. and air infiltration of four building facade orientations. Build. Environ., vol. 76, 2014, pp. 113-124.

[18] Cameron R.W.F., Taylor J.E., Emmett M.R. What's 'cool' in the world of green façades? How plant choice influences the cooling properties of green walls. Build. Environ., vol. 73, 2014, pp. 198-207.

[19] Huang Y.J. Akbari H. Taha A. etc. The potential of vegetation in reducing summer cooling loads in residential buildings. Climate Appl Meteorol., vol. 26, 1987, 1103e16.

[20] Sheweka S.M., and Mohamed N.M. Green facades as a new sustainable approach towards climate change. Energy Procedia, vol. 18, 2012, pp. 507-520.

[21] Larsen S.F., Filippín C., Lesino G. Thermal simulation of a double skin façade with plants. Energy Procedia, vol. 57, 2014, pp. 1763-1772. 